\title{
Prevalence of Zygomatic Air Cell Defects in a South Indian Population- A Retrospective Study
}

Bhargavi Dasari*, Ravi Kiran, Samatha Y, Udaya Sindu Y, Kartheeki B, Hima Bindu M, Purna Chandra Rao Nayak

Sibar Institute of Dental Sciences, Guntur, Andra Pradesh, India

*Corresponding author: Bhargavi Dasari, Sibar Institute of Dental Sciences, Guntur, Andra Pradesh, India, Tel: +917207499647; E-mail: bhargavibds@gmail.com Received date: July 13, 2016; Accepted date: July 25, 2016; Published date: August 05, 2016

Copyright: (c) 2016 Dasari B et al. This is an open-access article distributed under the terms of the Creative Commons Attribution License, which permits unrestricted use, distribution, and reproduction in any medium, provided the original author and source are credited.

\begin{abstract}
Background: Pneumatized air cells present in the zygomatic process of the temporal bone are termed Zygomatic Air Cell Defects (ZACDs). They are merely the extensions of the mastoid air cells anteriorly into the zygomatic process of the temporal bone which are important for surgical perspective. Panoramic radiography is useful to display these zygomatic air cell defects.
\end{abstract}

Aim: This study was undertaken to assess zygomatic air cell defects using digital panoramic radiograph.

Materials and methods: This involved retrospective evaluation of 1680 panoramic radiographs of patients of Indian origin.

Results: Out of 1680 radiographs, Zygomatic Air Cell Defects were seen in 41 panoramic radiographs with an overall prevalence of $2.4 \%$.

Conclusion: The overall prevalence of ZACDs is proportionally low but the diagnostitians and surgeons should be vigilant when dealing with zygomatic bone and thoroughly evaluate for zygomatic air cell defects.

Keywords: Zygomatic; Panaromic; Tempotal; ZACDs

\section{Introduction}

Pneumatization is the existence or development of airfilled cavities in a bone. The mastoid pneumatization begins in the 33rd week of embryonic life, and continues up to 8-9 years of age [1]. In addition to the pneumatization of the mastoid process, accessory air cells may evolve in numerous locations in the temporal bone, the root of the zygomatic arch and its articular eminence [2].

A nonexpansile, nondestructive cystlike radiolucency in the zygomatic process of the temporal bone, which appears similar to the mastoid air cell and which does not extend further anteriorly than the zygomaticotemporal suture entitled the Zygomatic Air Cell Defect (ZACD) [3] (Figure 1).
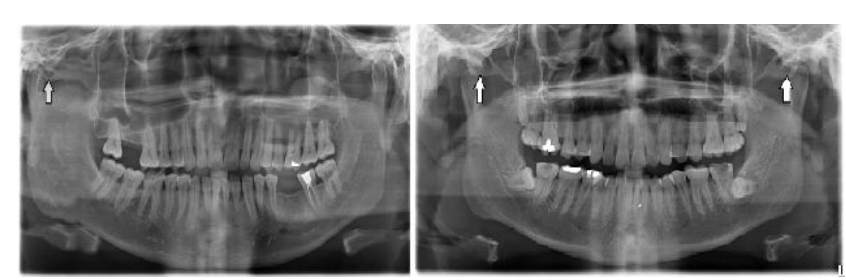

Figure 1: Panoramic radiograph showing unilateral and bilateral ZACDs

Tyndall and Matteson in 1987 offered a classification of ZACD into
- Unilocular type

- Multilocular type

- Trabecular type [3]

A unilocular ZACD appears as radiolucency with well-defined borders, while the multilocular type demonstrates numerous small cavities, which resemble mastoid air cells. The trabecular variety is basically a multilocular entity with internal bony striations.

More than the epidemiological view, the recognition of these air cells is important for surgical perspective too. Inadvertent penetration through this anatomic feature during surgical procedures can be disastrous [4]. The purpose of this study was to determine the prevalence and variations of ZACD in a selected Indian population.

\section{Subjects and Methods}

This is a retrospective study done on digital panoramic radiographs of patients with age range of 20-60 years who visited the Department of Oral Medicine and Radiology. The sample comprised of 1680 panaromic radiographs divided into three groups of 560 each, according to age.

Group I consisted of panaromic radiographs of patients in the age range of 20-29 years, groupII in the age range of 30-49 years, and group III in the age range of 50-59 years. Panaromic radiographs that have maxillofacial fracture history or maxillofacial anomalies were excluded from the study.

Panoramic radiographs of the subjects were taken using a panoramic unit (Sirona Orthophos XG) with an exposure of $71 \mathrm{kVp}, 8$ 
$\mathrm{mA}$, and 14.1 seconds. Radiographs were examined by an oral and maxillofacial radiologist and were evaluated for the presence of ZACDs

Patients were recorded as having ZACD only if unequivocal pneumatization of the root of the zygomatic arch or articular eminence posterior to the zygomatico-temporal suture appears as a well-defined uni- or multilocular radiolucency. The ZACDs were identified and grouped as unilocular or multilocular types and as unilateral or bilateral. The data was tabulated and subjected to statistical analysis.

\section{Results}

Mean age of the study subjects was 40 years. Out of 1680 subjects, ZACDs were found in 41 giving overall prevalence of $2.5 \%$.

Out of 41 ZACDs, 14 were in group-1 with a prevalence of $2.5 \%, 16$ were in group- 2 with a prevalence of $2.4 \%, 11$ were in group- 3 with a prevalence of $2.0 \%$ (Table 1 ).

In group-1, out of 14,8 were unilateral (1.4\%) and 6 were bilateral (1.1\%). Out of 8 unilateral, 4 were of male and 4 were of female. Out of 6 bilateral, 3 were of male and 3 were of female.

In group-2, out of 16,12 were unilateral (2.1\%) and 4 were bilateral $(0.7 \%)$. Out of 12 unilateral, 5 were of male and 7 were of female. Out of 4 bilateral, 2 were of male and 2 were of female.

In group-3, out of 11,6 were unilateral (1.1\%) and 5 were bilateral $(0.9 \%)$. Out of 6 unilateral, 1 /was of male and 5 were of female. Out of 5 bilateral, 3 were of male and 3 were of female (Table 2).

\begin{tabular}{|l|l|l|l|l|l|l|}
\hline Groups & $\begin{array}{l}\text { Age in } \\
\text { Years }\end{array}$ & $\begin{array}{l}\text { Number } \\
\text { of } \\
\text { Patients }\end{array}$ & Positive & $\begin{array}{l}\text { Unilatera } \\
\text { I }\end{array}$ & Bilateral & P Value \\
\hline Group A & $20-29$ & $560(100)$ & $14(2.5)$ & $8(1.4)$ & $6(1.1)$ & \multirow{2}{*}{0.464} \\
\hline Group B & $30-49$ & $560(100)$ & $16(2.9)$ & $12(2.1)$ & $4(0.7)$ & \multirow{2}{*yyyyn}{} \\
\cline { 1 - 5 } Group C & $50-59$ & $560(100)$ & $11(2.0)$ & $6(1.1)$ & $5(0.9)$ & \\
\hline
\end{tabular}

Table 1: Statistical Analysis: Chi-square test.

\begin{tabular}{|c|c|c|c|c|}
\hline Group A & Unilateral & Bilateral & Total & Result \\
\hline Male & $4(28.6)$ & $3(21.4)$ & $7(50)$ & \multirow[t]{3}{*}{$P=1.000$} \\
\hline Female & $4(28.6)$ & $3(21.4)$ & $7(50)$ & \\
\hline Total & $8(57.2)$ & $6(42.8)$ & $14(100)$ & \\
\hline Group B & Unilateral & Bilateral & Total & Result \\
\hline Male & 5 (31.3) & $2(12.5)$ & $7(43.8)$ & \multirow[t]{3}{*}{$P=0.771$} \\
\hline Female & $7(43.7)$ & $2(12.5)$ & $9(56.2)$ & \\
\hline Total & $12(75.0)$ & $4(25.0)$ & $16(100)$ & \\
\hline Group C & Unilateral & Bilateral & Total & Result \\
\hline Male & $1(9.1)$ & $2(18.2)$ & $3(27.3)$ & \multirow[t]{3}{*}{$P=0.987$} \\
\hline Female & $5(45.4)$ & $3(27.3)$ & $8(72.7)$ & \\
\hline Total & $6(54.5)$ & $5(45.5)$ & $11(100)$ & \\
\hline
\end{tabular}

Table 2: Statistical Analysis: Fisher's Exact test.

\section{Discussion}

Pneumatization refers to the development of air cell-like cavities in bone. Pneumatisation tackles with the formation of small osseous cavities created by normal periosteal activity. Primitive bone marrow in these cavities differentiates into a loose mesenchymal connective tissue. Epithelium invaginates into this connective tissue, producing a mucous membrane which then undergoes atrophy, leaving a thin residual lining membrane attached to the periosteum [4]. Continued subepithelial bone resorption further amplifies the air cells.

The term "Pneumatized Articular Tubercule" or "eminence" (PAT) was first used by Tyndall and Matteson to narrate an asymptomatic radiolucent lesion in the zygomatic process of the temporal bone with an appearance similar to the mastoid air cavities [3]. The defect might extend anteriorly as far as the articular tubercle but not beyond the zygomaticotemporal suture with no enlargement or cortical destruction of the zygoma. This entity was re-emphasized by Carter et al. and named as zygomatic air cell defect (ZACD) [5].

The importance of recognizing ZACD cannot be over emphasized. Temporal air spaces have been found to be potential pathways for the spread of pathological processes, cranial sepsis and infection [6]. Surgical procedures involving mandibular condyle and articular eminence can result in inadvertent penetration through the defect, and lead to dural tear and cerebro-spinal fluid leakage [7]. Moreover when ZACD is evident on the preoperative radiograph, eminoplasty or eminectomy are contraindicated [8].

The overall prevalence of ZACD in this study was $2.5 \%$ which showed higher prevalence compared to previous studies. The metaanalysis conducted by Carter et al., comprising of 4759 radiographs of previously published studies, uncovered an average prevalence of $1.7 \%$ [5]. A recent study by Selim et al. encompassing scrutiny of 8107 panoramic radiographs revealed the prevalence of ZACD to be $1.03 \%$. Another similar prospective investigation of South Indian population discovered the prevalence to be $2.5 \%$ [1].

The results of the present study supports those of Tyndall and Matteson in which the prevalence was $2.6 \%$ [3] and Park et al. in which the prevalence was $2.2 \%$ [9].

It has also been noted that certain other studies revealed no gender predilection. Hence it is difficult to reach a consensus on the gender prevalence of ZACDs. Previous reports state that ZACDs are hardly found in the latter half of second decade as the accessory air cells start the process of pneumatization only after puberty and achieve complete dimension several years after the mastoid cell [1]. The chances of detecting ZACD after the age of 60 years decreases, as suggested by Park and coworkers, who found no ZACDs above 60 years though their subject age ranged 2-91 years [9]. Therefore in this study individuals above 60 years and below 20 years were not included.

\section{Conclusion}

This research comprehensively scrutinizes the prevalence of ZACD and establishes the prevalence of ZACDs amongst Indians to be analogous with the other populations studied. This investigation after thorough examination of 1680 panoramic radiographs established prevalence of ZACDs to be $2.5 \%$, with dominance of the unilateral variants. Owing to the fragile and formidable nature of this entity diagnosticians and surgeons should be extra cautious when dealing with this entity to prevent the unexpected complications of the surgery. 
Citation: Dasari B, Kiran R, Samatha Y, Sindu YU, Kartheeki B, et al. (2016) Prevalence of Zygomatic Air Cell Defects in a South Indian Population- A Retrospective Study. Dentistry 6: 390. doi:10.4172/2161-1122.1000390

Page 3 of 3

\section{References}

1. Srikanth HS, Patil K, Mahima VG (2010) Zygomatic air cell defect: a panoramicradiographic study in a south Indian population. Ind J Rad Imaging 20: 112-114.

2. Zamaninaser A, Rashidipoor R, Mosavat F, Ahmadi A (2012) Prevalence of zygomatic air cell defect: Panoramic radiographicstudy of a selected Esfehanian population. Dental Res J 9: 132-135.

3. Tyndall D, Matteson S (1987) The zygomatic air cell defect (ZACD) onpanoramic radiographs. Oral Surg, Oral Med, Oral Pathol 64: 373-376.

4. Patil K, Mahimaa VG, Malleshib SN, Srikanth HS (2012) Prevalence of Zygomatic Air Cell Defect in adults-A retrospective panoramic radiographic analysis. Eur J Radiol 81: 957- 959.

5. Carter LC, Haller AD, Calamel AD, Pfaffenbach AC (1999) Zygomatic air cell defect (ZACD). Prevalence and characteristics in a dental clinic outpatient population. DentoMaxillofacRadiol 28: 116-122.
6. Orhan K, Delibasi C, Cebeci I, Paksoy C (2005) Prevalence and variations of pneumatized articular eminence: a study from Turkey. Oral surg Oral Med Oral Pathol Oral Radiol Endod 99: 349-354.

7. Yavuz MS, Aras MH, Gungor H, Buyukkurt MC (2009) Prevalence of the pneumatized articular eminence in the temporal bone. $J$ of Craniomaxillofac surg 37: 137-139.

8. Shokri A, Gangachin MN, Baharvand M, Mortazav H (2013) Prevalence and characteristics of pneumatized articular tubercle: First large series in Iranian people. Imaging Sci Dent 43: 283-287.

9. Park YH, Lee SK, Park BH, Son HS, Choi M, et al. (2002) Radiographic evaluation of the zygomatic air cell defect. Korean J Oral Maxillofac Radio 1 32: 207211. 